套路禁锢了创新

当代中国景观设计的保守主义

STEREOTYPE SHACKLES

CREATIVITY:

THE CONSERVATISM

IN CHINA'S CONTEMPORARY

LANDSCAPE DESIGN

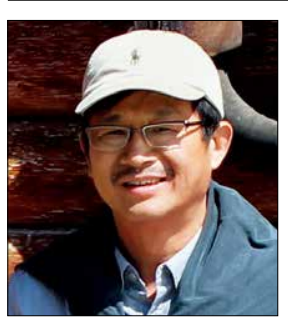

李建伟

东方园林首席设计师

北京市朝阳区酒仙桥北路甲10号院103楼7层, 由谝：100000

market@east la.cn

Jianwei LI

Chief Designer, Orient Landscape and Environment Group
1 “新中式” 套路

在中国这片土地上，任何设计都绕不开 “中国文化”这个敏感的话题。前些年，在 中国设计行业中盛行的“欧陆设计风”使得 国内大量景观设计模仿国外设计作品, 出现 了很多异国风情的居住区及商业空间。作为 对这种“复制文化”的对抗，一批誓把中国 传统文化发扬光大的设计师开始刻意追求将 中国人自己的文化语言运用到家具、装饰、 建筑、景观等诸多设计领域。在这样的背景 下，“新中式”开始成为一个时髦的概念。 设计师们用以表现中国文化最直接的方式, 就是将一些人人熟知的“中国元素”引入设 计。对于所谓的中国元素，设计师们信手拈 来: 苏州园林的拱桥、北京胡同的门栓、梅 兰竹菊“四君子”、松竹梅“岁寒三友” 灯笼剪纸、白墙青瓦、爆竹烟花、玉石泥 塑、京剧脸谱、舞狮舞龙、绣花小鞋，还有 那边歌边舞的“好一朵茉莉花” ……甚至不
少外国设计师也把这些当作进入中国市场的 敲门砖。久而久之形成了一种“套路”： 设计若要体现中国文化, 必有这些中国元 素——这仿佛成为了设计竞争中百战百胜的 “护身符”。

文化元素的反复使用是景观设计走向同 质化的体现, 模式化的思维和工作方法很可 能使我们落入俗套而不自知。设计一旦落入 某种套路, 就不再有思想自由驰骋的疆域, 设计就会像流水线上的产品一样, 丧失了独 特性。而更加令人遗憾的是, 在这种文化背 景下教育出来的年轻学子, 他们中的大多数 人思想禁锢, 且不具备批判性思维。一谈设 计, 张口必是: 步移景异、曲径通幽、欲扬 先抑、天人合一……如背诵乘法口诀一般。

\section{2 设计不是为人民服务的}

“新中式”抛弃了“欧陆设计风”的 套路，取而代之的却是自己的套路。这种停 https://doi.org/10.15302/J-LAF-20170609 $\mid \begin{aligned} & \text { 收稿日间 RECEIVED DATE / 2017-10-26 } \\ & \text { 中图分类号 / TU986 }\end{aligned}$ 文献标识码/B
摘要

本文就当代中国景观设计行业中的“新中式” 运动进行了批判, 认为 中国元素的滥用已经导致了景观设计的同质化，并直指其盛行的原因是中 国当前设计领域中普遍存在的狭隘的保守主义。文章继而就中国文化如何 在当代景观设计中展现的问题展开讨论, 分别对景观文化以及中国文化的 层次和维度进行了梳理, 并指出设计师应当跳脱出场地尺度的设计, 而要 拥有更加宏大的视野、承担更大的社会责任。

\section{关键词}

中国元素; 中国文化; “新中式” 景观设计; 保守主义; 设计创新; 艺术

\section{ABSTRACT}

This paper starts with criticizing the design tide of Neo Chinese-style in China's contemporary landscape design, where it argues that the indiscriminate use of Chinese elements in landscape design has terribly deadened design uniqueness and diversity, and points out that the

popularity of Neo Chinese-style mirrors the narrow conservatism prevalent in China's contemporary design industry. The article also explores the topic of how to celebrate the Chinese culture in contemporary landscape design by reviewing the levels and dimensions of landscape culture and Chinese culture, with an argument that designers ought to have a broader horizon with a greater social responsibility.

\section{KEY WORDS}

Chinese-style Element; Chinese Culture; Neo Chinese-style Landscape Design; Conservatism; Design Creativity; Art

\section{整理 田乐}

泽田乐

EDITED BY Tina TIAN

TRANSLATED BY Tina TIAN 
留在表面的设计包装之所以盛行, 是因为为 之买单的人不在少数, 包括开发商、政府部 门、使用者, 以及媒体。而这背后体现出的 是中国当前设计领域中普遍存在的狭险的 保守主义。

的确, 所有的作品都必须在满足功能和 使用需求的前提下来谈设计。但设计不是为 人民服务的一一这里指的是设计的艺术创作 和思想。艺术一定是设计师自身真实意愿和 情感的表达。如果一味地去揣测和迎合大众 的爱好, 那么设计师只是一个窥探者, 而非 思想独立的艺术家。但是, 需要警醒的是, 艺术从来没有绝对的正确, 而且永远存在犯 错和被淘汰的可能。设计行业要有允许试错 的包容精神一一如果民众的思想一直被保守 主义左右而不允许试错的发生, 那么这个社 会就永远不会诞生好的设计作品。

\section{3 中国元素不等于中国文化}

在这里, 笔者并不是反对传统元素的运 用。我们需要明白, 设计中运用了中国传统 元素, 不等于该设计就体现了中华民族精神 和中国文化。

景观文化的表现无论从实体形象上还 是从思想观念、行为方式上都有表层、浅层 和深层的区别: 表层即作用于视觉表象的、 非本质的文化表现形式, 前文例举的多属此 列 ; 浅层即在一定时期和一定空间地域范围 内, 在一定程度上表达了中国文化的属性 (例如, 民族风俗, 以及音乐、诗歌等艺术 形式）；深层文化体现相对而言具有长效性 和典型性, 其反映的是内在的文化基因, 包 括体现民族和自然特质的文化内涵。由此可 见, 景观文化是一个非常复杂的综合体, 是
不断传承演化的历史过程。

在这里, 我们有必要从时间和空间两个 维度来理解中国文化。其一，中国文化的一 大要素就是地域性。地域性是文化的基石, 有了地域性才有将文化融入自然环境之中的 可能。地域的差异不但造就了一个民族与其 他民族的差异性，同时也为本民族的多样性 提供了可靠的生存土壤。中国是个自然风景 资源极其丰富多样的国家，如果这些都不 能成为景观设计师最值得自豪且热衷于表 达的, 那我们岂不是在幸负这一片深情的 土地?

其二，中国的文化是中国人生活的基 本方式及其社会结构。历史和文脉是一条延 续的河流，把文化定格在某一个历史时间点 或某一个空间范围都是不可取的。值得借鉴 的历史是祖先的遗存, 是我们现在立足的根 基。我们要用新的眼光来看待历史, 每一次 创作都应该是对传统的重新认识和对未来的 勇敢探索。

正如著名设计师靳埭强所说：“我们 不一定要画上京剧的脸谱, 穿上龙袍, 才能 让人认出自己是中国人……我们完全可以使 用非常国际化的符号，而表达的思想可以是 中国的，是中国文化的。”[1]我们正处于全 球文化大融合的时代，生命的多样性令我们 欢欣鼓舞。作为世界文明的组成部分，中 国文化最主要的存在价值在于其对世界的贡 献。新时代的景观设计应该是对中国人民的 生活, 以及这片土地的一种与时俱进的表达。

\section{4 被禁铜了的创新}

在期盼新一轮的经济崛起和文化复兴 的中国，人人都在寻求创新发展的路径。作
为创意行业的景观设计肩负着传承与创新的 双重使命。对历史的传承和发扬光大是每一 代设计师共同的情怀。但是，作为“创新理 念” 而提出的“新中式” 运动不但没有把我 们引向美好的明天, 反而留下了一地鸡毛!

创新是什么? 创新就是在当代语境下解 决当下的问题。中国设计的基本内容是在当 代全球化背景下演绎中国的价值观。如何认 识中国文化与现代设计的关系, 并使其在现 代设计中得到更具生命力的展现, 是我们共 同的议题。

此外，设计师应首先关心大问题，而后 讨论具体设计。每一个细小的事物都要有一 个大的系统来支撑。只有解决了大的问题, 才有可能解决小的问题。设计师不能只关心 自己笔下的小公园、小绿地 (在中国, 城市 仅占国土面积的3\%，而城市绿地又仅占城 市面积的 $30 \%$ ），应该更多地把目光投向那 些能够为国家的发展壮大带来福祉的事情, 考虑如何使我们的设计体现对自然的敬畏、 对人性的关怀、对历史的保护 ; 如何使场地 与场地周边的山水相呼应、如何与地貌相符 合、如何与水流相联系 ; 如何使我们的视野 跳脱出城市的范围, 将整个乡村地区, 以及 国土尺度上的森林、湿地、沙漠、水系全部 纳入到设计范围当中; 如何使我们的设计不 仅仅着眼于人类的生存，而是服务于地球上 的所有生物。LAF

注释

本文部分内容由《景观设计学》与李建伟于2017年11月2日的访谈 整理而成。采访: 田乐、王颖、王楠。东方园林东方易地景观设 计有限公司黄傿女士及《景观设计学》实习编辑张晶览对本文亦 计有限公
有贡献。 


\section{The So-called Neo Chinese-style Landscape Design}

In China, no design industry can be completely separated from Chinese culture. In the past few years, when European-style design prevailing in China's design industries, a large number of landscape projects imitated foreign design works, resulting in many exotic residential and commercial space built. Against this blind imitation, lots of native designers with an ambition to carry forward the Chinese traditional culture ideals began to use Chinesestyle elements in furniture, decoration, architecture, landscape and many other design areas, wantonly. Neo Chinesestyle design, raised since then as a fashionable concept, started to be widely received. Indiscriminately, most designers attempt to embody Chinese culture by introducing some well-known Chinesestyle elements into their design, such as the arch bridges in Chinese traditional private gardens; the door bolt of Beijing hutongs; plum blossoms, orchid, bamboo, chrysanthemum, and pine which are favorite plants of Chinese traditional scholars; red lantern and paper-cuttings; white walls and grey tiles; firecrackers and fireworks; jade decoration and clay figurine; Peking Opera facial makeup and dragon dance; embroidered shoes and the famous aria from Opera Turandot.... Quite often, foreign designers take this kind of assorted design to please their Chinese clients' fancy. Seemingly, in China, Chinese culture can only be expressed with Chinese elements, as if it is a magic routine to win projects.

However, the magic routine has killed the creativity in China's contemporary landscape design and terribly limited designers' outlook and working methods. Sadly, they are blissfully unaware of it. Once a design is on some kind of beaten track, there is no more creative sparkles: the design would become a factory-made product, without any uniqueness. More regrettably, most students and young designers are taught and trained in this cultural context and their creativity is shackled by these stereotypes, having no critical thinking at all; when it comes to design, what all they know is to follow the design methods handed down, just like reciting multiplication rhymes.

\section{Design Is not to Please the Public}

Ironically, developed to challenge the stereotype of exotic-style design, Neo Chinese-style design contents itself with another stereotype. The popularity of Neo Chinese-style design mirrors the narrow conservatism prevalent in China's contemporary design industry, from developers and governmental agencies to users and media.

Indeed, the primary objective of a design is to meet the requirements of function and usage. But design is not to please the public - here, the artistic creativity of a design is referred to. Art is an expression of the designer's true sentiments, instead of a work created to please its audience. Designers need to have an independent artistic aesthetic and critical thinking. But what we need to be aware of is that there is never a correctness in art, and every art work has a possibility to be faulty and obsolete. In design industries, it is important to have tolerance to trial and error. Good works will never be born in a culturally and socially conservative aura.

\section{Chinese Culture and Its Reflection in Design}

Here, the author does not mean to oppose the use of traditional Chinese elements in landscape design; Instead, one argues that Chinese symbols are not equated with Chinese culture or the spirit of China.

Landscape culture consists of different levels, in forms, concepts, and manners. At a superficial level, landscape culture is often understood as visual images which, however, are culturally peripheral (including most of the examples mentioned). At a simple level, landscape culture represents some attributes of Chinese culture with temporal and regional characteristics (for example, folk customs, as well as music, poetry, and other art forms). At an essential level, landscape culture reflects what is culturally inherent and classic, including the cultural connotation of the national and natural qualities. Hence, landscape culture is a complex expression about the historical 
process of inheritance and evolution.

It is necessary for us to understand Chinese culture from dimensions of time and space. First, regionality is the cornerstone of culture, which gives the possibility of linking and integrating culture with natural environment. Differences in regionality not only define the distinctive quality of a nation, but also support the national diversity. China is a country rich in natural landscape resources, which should be the source of creativity we feel proud of and love to express about.

Secondly, Chinese culture lives in Chinese people's life and China's social structure. Time moves on and leaves history behind. The whole historical spirit cannot be represented only by some cultural pieces of a certain period or a specific territory. We do need to learn from history, and more importantly, we need to examine history from a new and critical perspective. Design is a creation stemmed from designers' understanding of history and heritage and courageous exploration towards the future.

As Tai-keung Kan, a renowned modern designer, said: "We do not have to wear a Beijing Opera facial makeup, or put on a dragon robe to make ourselves recognized as a Chinese.... Highly international elements can be used to express Chinese spirit and Chinese culture. ${ }^{[1]}$ We are in the age of celebrating cultural fusion and diversity. As an integral part of world civilization, Chinese culture exists to contribute to the world. In this new era, China's landscape design needs to focus on people's life and the land where people live.

\section{Imprisoned Innovation}

With the rapid economic growth and cultural revival in China, innovation and development become twin pressing topics of the era, particularly to landscape design, a profession of creativity. The question that how to pass on and carry forward the cultural heritage inspires all of us. However, the Neo Chinese-style landscape design, developed as a design innovation, has brought us nothing but a hotchpotch.

Then, what is innovation? Innovation is to solve present problems in contemporary context. Basically, Chinese designers' philosophy and their thinking under the global background can be reflected through their work. It is a common agenda for them to understand and explore Chinese culture in modern context, and to make it more diverse and vitalized with design.

In addition, it is always important to see a big picture first. Every small thing is supported by a larger system, and every small decision should be considered in a larger context. Designers need to think big, beyond the small-scale design of parks and green spaces - in China, urban area accounts for only $3 \%$ of the total national territory, of which urban green space only takes a portion of $30 \%$. Designers need to consider how to promote the healthy development of the country and to enhance people's wellbeing through their design, such as how do we respect the nature? How to reflect humanity and history? How to make the site harmonized with its surrounding landscapes? How to connect the site with its topographical and hydrological context? How can we expand our design territory to the rural areas, forests, wetlands, deserts, and water systems at a national scale? And, how to make our design serve not only the mankind, but also all the living beings on Earth? LAF

NOTE

The article is partly regenerated from an interview between Landscape Architecture Frontiers (LA Frontiers) journal and the author on November 2, 2017 linterviewers: Tina Tian, Ying Wang, and Nancy Wangl. Ms. Xin Huang from Orient Landscape, and Ms. Jingrui Zhang, intern at LA Frontiers also contributed to this article.

REFERENCE

[1] Kan, T. K. (2003). From Life to Mind: Kan Tai-keung's Design and Art. Shantou: Shantou University Press. 